\author{
ACTA MYCOLOGICA \\ Vol. 43 (1): 29-40 \\ 2008
}

\title{
Impact of selected antagonistic fungi on Fusarium species - toxigenic cereal pathogens
}

\author{
DELFINA POPIEL ${ }^{1}$, HANNA KWAŚNA ${ }^{2}$, JERZY CHELKOWSKI ${ }^{1}$, \\ ŁUKASZ STEPIEN ${ }^{1}$ and MAGDALENA LASKOWSKA ${ }^{3}$ \\ ${ }^{1}$ Institute of Plant Genetics, Polish Academy of Sciences, \\ Strzeszyńska 34, PL-60-479 Poznań, jche@igr.poznan.pl \\ ${ }^{2}$ Department of Forest Pathology, Agricultural University, Wojska Polskiego 71c, PL-60-625 Poznań \\ ${ }^{3}$ Department of Chemistry, Agricultural University \\ Wojska Polskiego 75, PL-60-625 Poznań
}

Popiel D., Kwaśna H., Chełkowski J., Stępień Ł., Laskowska M.: Impact of selected antagonistic fungi on Fusarium species - toxigenic cereal pathogens. Acta Mycol. 43 (1): 29-40, 2008.

Fusarium-ear blight is a destructive disease in various cereal-growing regions and leads to significant yield and quality losses for farmers and to contamination of cereal grains with mycotoxins, mainly deoxynivalenol and derivatives, zearalenone and moniliformin. Fusarium pathogens grow well and produce significant inoculum on crop resiudues. Reduction of mycotoxins production and pathogen sporulation may be influenced by saprophytic fungi, exhibiting antagonistic effect.

Dual culture bioassays were used to examine the impact of 92 isolates (belonging to 29 fungal species) against three toxigenic species, i.e. Fusarium avenaceum (Corda) Saccardo, F. culmorum (W.G.Smith) Saccardo and F. graminearum Schwabe. Both F.culmorum and F. graminearum isolates produce trichothecene mycotoxins and mycohormone zearalenone and are considered to be the most important cereal pathogens worldwide. Infection with those pathogens leads to accumulation of mycotoxins: deoxynivalenol (DON) and zearalenone (ZEA) in grains. Fusarium avenaceum isolates are producers of moniliformin (MON) and enniatins. Isolates of Trichoderma sp. were found to be the most effective ones to control the growth of examined Fusarium species. The response of Fusarium isolates to antagonistic activity of Trichoderma isolates varied and also the isolates of Trichoderma differed in their antagonistic activity against Fusarium isolates. The production of MON by two isolates of $F$. avenaceum in dual culture on rice was reduced by $95 \%$ to $100 \%$ by $T$. atroviride isolate AN 35. The same antagonist reduced the amount of moniliformin from $100 \mu \mathrm{g} / \mathrm{g}$ to $6.5 \mu \mathrm{g} / \mathrm{g}$ when inoculated to rice culture contaminated with $\mathrm{MON}$, which suggests the possible decomposition of this mycotoxin.

Key words: antagonistic fungi, Fusarium, moniliformin, Trichoderma 


\section{INTRODUCTION}

Fusarium species are cosmopolitan necrotrophic pathogens of cereals, pulse crops and many other plants, important in Agricultural and forest landscape. Fusarium ear (head) blight $(\mathrm{FHB}=\mathrm{scab})$ has been known for more than 100 years and is one of the important diseases of wheat and other small grain cereals. In Europe it is caused mostly by $F$. graminearum, F. culmorum, F. avenaceum and F. poae. Other Fusarium species are less important due to their lower incidence and aggressiveness (Arseniuk et al. 1999; Bai, Shaner 1994; Parry et al. 1995; Chełkowski 1998; Wakuliński, Chełkowski 1993; Bottalico, Perrone 2002). FHB leads to significant loss of grain yield and quality. Several fungal secondary metabolites, e.g. deoxynivalenol (DON), nivalenol (NIV), zearalenone (ZEA) and moniliformin (MON) and also their derivatives may contaminate cereal grains (McMullen et al. 1997; Jones, Mirocha 1999; Bottalico 1998; Chełkowski 1998). The disease has been re-emerging in many cereal-growing regions worldwide (Parry et al. 1995; McMullen et al. 1997; Jones, Mirocha 1999; Bottalico, Perrone 2002).

Three chemotypes are common within F. culmorum and F. graminearum species: nivalenol (NIV), 3acetyl-deoxynivalenol (3-AcDON) and 15acetyl-deoxynivalenol (15-AcDON). These chemotypes can be identified by chemical analyses of fungal cultures or by chemotype-specific DNA markers (Quarta et al.2005).

Fusarium culmorum and F. graminearum survive saprophytically on plant residues after harvest and serve as a source of inoculum for the subsequent year. Both species colonize particularly frequently maize stalks and $F$. graminearum produces significant amounts of ascospores and conidia (Sutton 1982). Fusarium avenaceum is a cosmopolitan species and one of the most important ones in agriculture and the forest environment in the moderate climatic zone (Nelson et al. 1983; Kwaśna et al. 1991; Leslie, Summerell 2006).

Simultaneous co- occurrence of the three mycotoxins: monilformin, deoxynivalenol and nivalenol was found in high percentage of positive samples (33\% and $35 \%)$, during 1998 and 1999 epidemics of FHB in wheat in Poland (Tomczak et al. 2002).

There are few species among soil microorganisms antagonistic to Fusarium, able to reduce their population in soil and debris. Several fungal species were examined for the ability to reduce the inoculum potential of Fusarium pathogens, mainly by reduction of biomass in plant residues colonized by Fusarium (Eacicowa, Pięta 1985; Ligitt et al. 1997; Luongo et al. 2005; Lutz et al. 2003; Dawson et al. 2004). Several antagonists were found to reduce infection of ears and accumulation of DON in wheat grains (Ligitt et al. 1997; Dawson et al. 2004). Clonostachys, Gliocladium and Trichoderma species reduced the colonization of wheat and maize by pathogenic Fusarium species and suppressed the sporulation of the latter (Woo et al. 2005; Luongo et al. 2005). There is only scarce information on fungal antagonists of toxigenic Fusarium species and their ability to reduce the production of mycotoxins in solid substrates. Trichoderma species have been examined for more than 50 years and are known as highly effective in biological control of a wide range of plant pathogens of soil origin. They are also known to produce over 120 secondary metabolites, including antifungal metabolites (Kubicek, Harman 1998; Woo et al. 2005).

Cooney et al. (2001) showed that 6-pentyl-alpha-pyrone (6PAP), which is a metabolite of $T$. harzianum (THF2/3), can reduce the production of deoxynivalenol 
by $F$. graminearum on agar medium by 66 to $81 \%$. The authors developed an agar bioassay technique to examine Fusarium-Trichoderma interaction on their secondary metabolites level.

T. harzianum type 4 and named T. aggressivum has been found recently to be competitor of commercial mushroom Agaricus bisporus, known to be the cause of green mold and significant losses to mahrooms producers (Savoie, Mata 2003).

The aim of this paper was to examine the effect of 29 fungal species isolates (including Trichoderma) originated from soil, compost and cereals, on the growth of three toxigenic Fusarium species in dual cultures and a mutual interaction between the antagonists and Fusarium isolates in bioassays, and to examine the reduction of moniliformin production in dual cultures of $F$. avenaceum with selected effective Trichoderma antagonists.

\section{MATERIAL AND METHODS}

Fungal isolates. Isolates of tested fungi originated from culture collections of the Institute of Plant Genetics, Polish Academy of Sciences, Poznań, Poland (KF and AN), the Institute of Science of Food Production, Bari, Italy (ITEM) and the Department of Forest Pathology, Agricultural University, Poznań, Poland (Tab. 1). Fungal isolates originating from soil, compost and cereal grains were maintained on a synthetic low nutrient agar SNA (Nirenberg 1981; Kwaśna et al.1991). Identification and nomenclature of Trichoderma and Gliocladium isolates was followed according to Gams and Bissett 1998.

Fusarium isolates - species and chemotype identification. Species were identified based on their macroconidia structure using an Olympus optical microscope at a 400-500x magnification according to Nelson et al. (1983), Kwaśna et al. (1991) and Nirenberg (1981) manuals. Species identification was also performed using DNA markers. Fungal DNA was extracted using the modified CTAB method (Chełkowski et al. 2002). PCR amplification mixture consisted of $0.5 \mathrm{U}$ of Taq DNA polymerase (Finnzymes), $2.5 \mu \mathrm{l}$ of PCR buffer, $12.5 \mathrm{pmol}$ of forward/reverse primers, $2.5 \mathrm{mM}$ of each dNTP and about $10 \mathrm{ng}$ of fungal DNA. For the identification of $F$. culmorum, $F$. graminearum and $F$. avenaceum species, the following markers were used: $\mathrm{Fc01}$ (570 bp), UBC85 (332 bp), Fg16N (280 bp), Fa (920 bp) (Nicholson et al. 1998; Schilling et al. 1996, Doohan et al. 1998) and to identify 3Ac-DON, 15Ac-DON and NIV chemotypes Tri3 (708 and 354 bp) and Tri7 (625 bp) markers were used (Quarta et al. 2005).

Dual culture bioassays. A modified bioassay of Mańka (1974) was applied to examine growth reduction of three toxigenic species isolates: $F$. avenaceum, $F$. culmorum and F. graminearum. A Fusarium isolate and a tested fungus (an antagonist) were inoculated onto $9 \mathrm{~cm}$ Petri dishes at a distance of $1 \mathrm{~cm}$ on potato dextrose agar (PDA). As a control each fungus was cultured separately. Agar plates were then incubated at $25^{\circ} \mathrm{C}$ at diffused daylight. Inhibition of Fusarium growth by the antagonist was evaluated using a modified Mańka (1974) scale -8 to +8 presented in figure 1 , where 0 indicated no inhibition and +8 a total inhibition, with the Fusarium mycelium in $>95 \%$ overgrown by the antagonist. Growth rate of each control culture was measured after 2-7 days. At least two replications were performed. 
Table 1

Growth rate of 92 candidate antagonistic isolates from soil, compost and cereals and Fusarium isolates on PDA medium in $\mathrm{mm}$ /day at $25^{\circ} \mathrm{C}$

\begin{tabular}{|c|c|c|c|c|}
\hline $\begin{array}{l}\text { Species } \\
\text { group }\end{array}$ & Species of potential competitors & $\begin{array}{l}\text { No. of } \\
\text { isolates }\end{array}$ & $\begin{array}{l}\text { Accession code } \\
\text { (AN) }\end{array}$ & $\begin{array}{l}\text { Mean growth } \\
\text { rate } \mathrm{mm} / \text { day }\end{array}$ \\
\hline I & Trichothecium roseum (Pers; Fries) Link & 1 & 27 & 10 \\
\hline II & Trichoderma viride Pers. \& Fries & 12 & $\begin{array}{c}14,15,16,17,18, \\
45,46,47,48,51, \\
52,61\end{array}$ & $11-21$ \\
\hline III & Trichoderma pseudokoningii Rifai & 1 & 60 & 21 \\
\hline IV & Trichoderma polysporum Link: Pers & 1 & 55 & 20 \\
\hline $\mathrm{V}$ & Trichoderma longibrachiatum Rifai & 1 & 22 & 21 \\
\hline VI & Trichoderma koningii Oudemans & 4 & $49,59,65,66$ & 21 \\
\hline VII & Trichoderma harzianum Rifai & 12 & $\begin{array}{c}3,4,5,6,13,53 \\
54,58,62,63 \\
64,94\end{array}$ & $21-31$ \\
\hline VIII & Trichoderma hamatum (Bon) Bainier & 2 & 21,56 & $20-21$ \\
\hline IX & Trichoderma citrinoviride Bissett & 1 & 89 & 31 \\
\hline $\mathrm{X}$ & Trichoderma aureoviride Rifai & 1 & 57 & 21 \\
\hline XI & Trichoderma atroviride Karsten & 4 & $19,35,50,90$ & $21-30$ \\
\hline XII & $\begin{array}{l}\text { Trichoderma asperellum Samuels, Lieckf. } \\
\text { \& Nirenberg }\end{array}$ & 1 & 93 & 25 \\
\hline XIII & Pythium sp. & 1 & 72 & 7 \\
\hline XIV & $\begin{array}{l}\text { Paecilomyces carneus (Duché \& R. } \\
\text { Heim) A.H.S. Br. \& G. Sm. }\end{array}$ & 1 & 42 & 1 \\
\hline $\mathrm{XV}$ & Paecilomyces farinosus Holmskjold & 1 & 41 & 1 \\
\hline XVI & Mortierella sp. & 1 & 71 & 14 \\
\hline XVII & Melanospora fimicola E.C. Hansen & 3 & $29,31,44$ & 6-21 \\
\hline XX & Idriella bollei Sprague & 1 & 83 & 18 \\
\hline XVIII & Hypocrea hипиа Dingley & 1 & 20 & 21 \\
\hline XIX & $\begin{array}{l}\text { Gliocladium virens J.H. Mill., Giddens \& } \\
\text { A.A. Foster }\end{array}$ & 6 & $\begin{array}{l}68,69,70,73 \\
74,75\end{array}$ & $20-21$ \\
\hline XXI & Gliocladium roseum Bainier & 4 & $24,25,26,78$ & $2-7$ \\
\hline XXII & Gliocladium catenulatum Glim \& Abbot & 4 & $23,32,43,88$ & $7-9$ \\
\hline XXIII & Gilmaniella sp. & 4 & $67,76,77,79$ & $5-7$ \\
\hline XXIV & Fusarium flocciferum Corda & 3 & $84,85,86$ & 7-13 \\
\hline XXV & Fusarium equseti (Corda) Sacc. & 7 & $\begin{array}{l}1,2,7,9,10 \\
11,12\end{array}$ & $5-15$ \\
\hline XXVI & Epicoccum nigrum $\mathrm{Link}$ & 6 & $\begin{array}{c}36,37,38,39 \\
40,87\end{array}$ & $2-12$ \\
\hline XXVII & $\begin{array}{l}\text { Cladosporium cladosporioides (Fr.) de } \\
\text { Vries }\end{array}$ & 2 & 81,82 & $17-19$ \\
\hline XXVIII & Chaetomium cochlioides Palliser & 4 & $28,30,33,34$ & $12-21$ \\
\hline \multirow[t]{2}{*}{ XXIX } & Acremonium sp. & 1 & 80 & 5 \\
\hline & Fusarium sp. & & & \\
\hline $\mathrm{XXX}$ & Fusarium avenaceum (Corda) Sacc. & 2 & & 15 \\
\hline XXXI & Fusarium culmorum (W.G.Smith) Sacc. & 3 & & 19 \\
\hline XXXII & Fusarium graminearum Schwabe & 13 & & $9-20$ \\
\hline
\end{tabular}

To examine the reduction of Fusarium toxin production in solid substrates $50 \mathrm{~g}$ of commercial rice were soaked with $15 \mathrm{ml}$ of distilled water in a $300 \mathrm{ml}$ Erlenmayer flask overnight before sterilization run for $30 \mathrm{~min}$. at $121^{\circ} \mathrm{C}$. Then it was inoculated with Fusarium and the tested fungus (antagonist). Inoculation was made with four $4 \mathrm{~mm}$ diameter discs of each fungus cut from the edge of 1-week-old culture on PDA and $2 \mathrm{ml}$ of sterile water. Cultures were incubated at $25^{\circ} \mathrm{C}$ and shaken each day to support a uniform growth of mycelium. In the control each fungus was cultured 


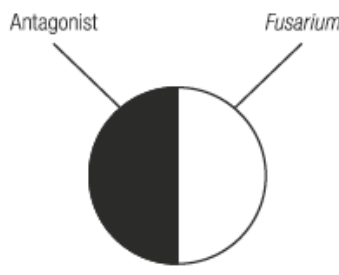

0

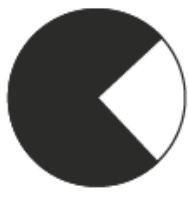

$+4$

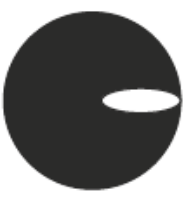

$+6$

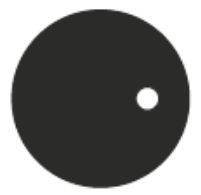

$+8$

Fig. 1. Schematic presentation of scale used for evaluation of Fusarium isolates growth rate reduction by candidate antagonistic fungi.

separately. After 21 days rice colonized by fungi was dried in a thin layer at room temperature and mycotoxin content was analyzed. Two replications were made for each combination of paired cultures and for each control. Fusarium avenaceum isolate KF 2603 (ITEM 3411) rice culture, producing high amounts of moniliformin, was microwaved to kill mycelium cells and inoculated with the AN 35 T. atroviride isolate. After 21 days of inoculation at $25^{\circ} \mathrm{C}$ the culture was dried as above and prepared for MON analyses.

Mycotoxin analyses. Moniliformin content in dry rice was analyzed by HPLC described in details by Tomczak et al. (2002) with $90 \%$ MON recovery and detection limit of $10 \mu \mathrm{g} / \mathrm{kg}$.

\section{RESULTS AND DISCUSSION}

Fast growth is important character for a potential antagonist used in biological control of plant pathogens. It suggests strong competition for nutrients and space, which is very useful for the inhibition and possible elimination of pathogens. Growth rates of the examined Fusarium antagonists varied between species and isolates. Considering the growth rate on PDA, 92 isolates were divided into 3 groups:

1. Fast growing isolates with a growth rate $>20 \mathrm{~mm} /$ day,

2. Moderately growing isolates with a growth rate of $10-20 \mathrm{~mm} /$ day,

3. Slowly growing isolates with a growth rate $<10 \mathrm{~mm} /$ day.

The first group contained mostly Trichoderma species (the number of isolates is given in brackets), i.e.: T. atroviride (4), T. aureoviride (1), T. asperellum (1), T. citrinoviride (1), T. hamatum (1), T. harzianum (12), T. koningii (4), T. longibrachiatum (1), T. pseudokoningii (1), T. viride (10) and several isolates of different species: Melanospora fimicola (1), Gliocladium virens, syn. T. virens (5), Chaetomium cochlioides (1) and Hypocrea hunua (1). The following belonged to the second group: Trichothecium roseum (1), Fusarium equiseti (6), Mortirella sp. (1), Idriella bolei (1), Cladosporium cladosporioides (2), Epicoccum nigrum (2), Chaetomium cochlioides (3), Gliocladium virens (1) and a limited number of Trichoderma isolates. The following were included in the last group: Epicoccum nigrum (4), Paecilomyces farinosus (1), Paecilomyces carneus (1), Gliocladium roseum (4), G. catenulatum (3), Gilmaniella sp. (4), Melanospora fimicola (2), Phytium sp. (1), Acremonium sp. (1) and Fusarium equiseti (1).

Growth rates of Fusarium species, i.e. F. avenaceum, F. culmorum and F. graminearum isolates, were lower than growth rates of the first group of the antagonists and 


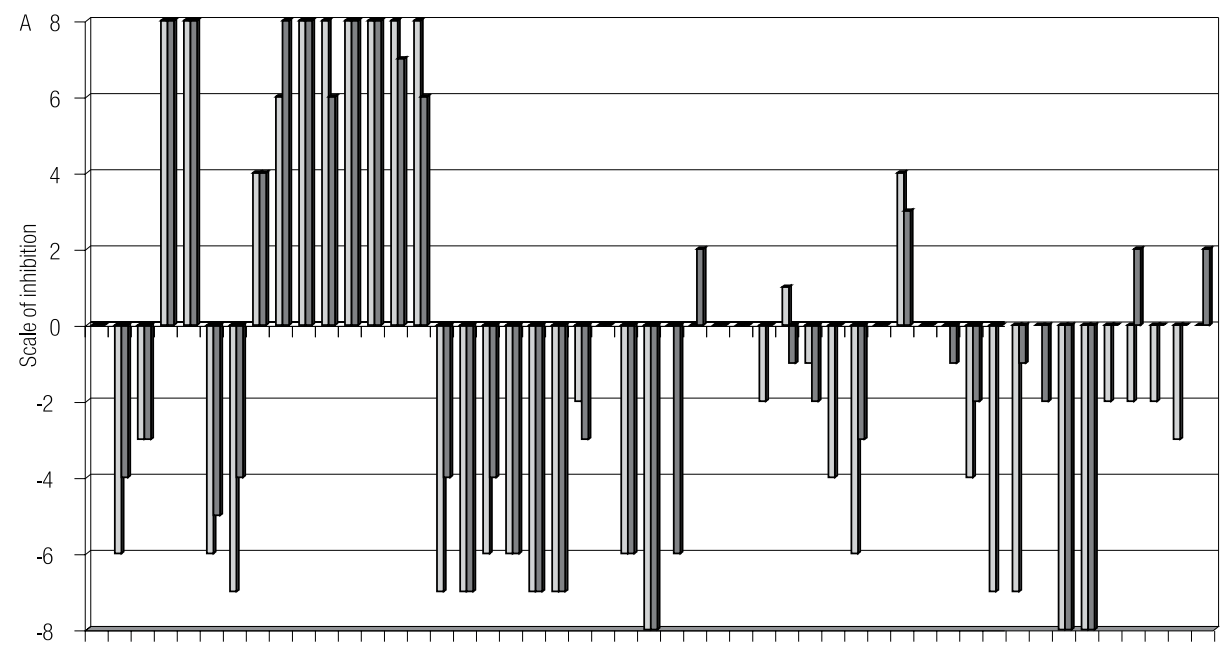

NभFT:

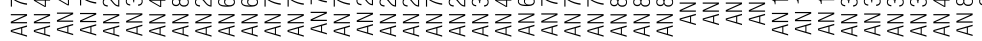

Accession code

Mean inhibition for isolate KF 2870

Mean inhibition for isolate KF 844

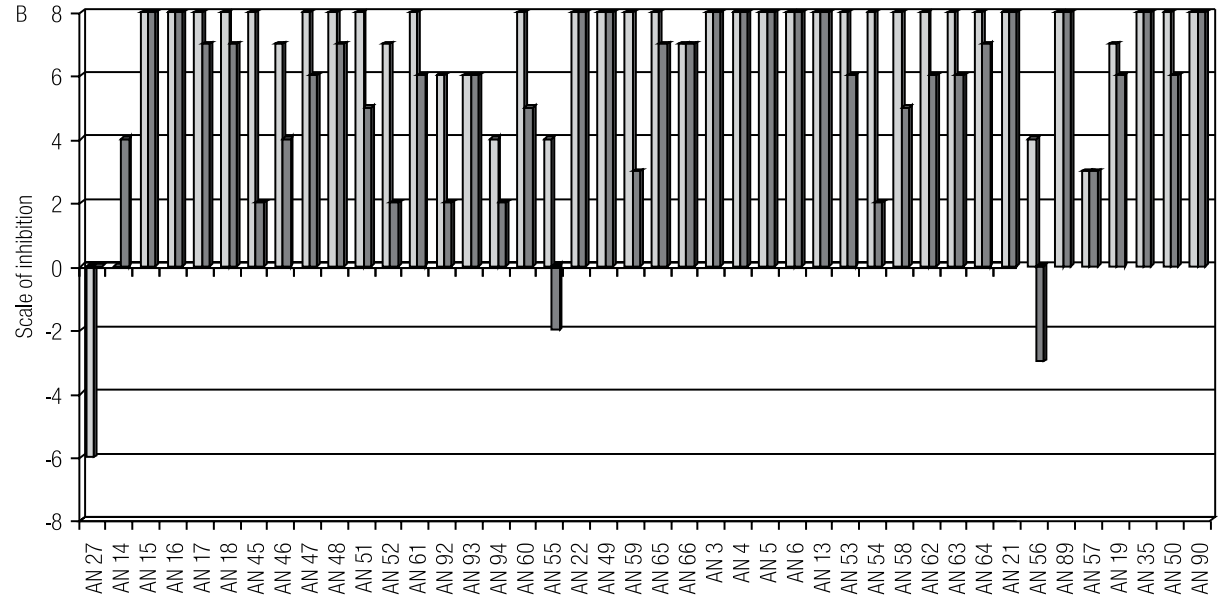

Accession code

Mean inhibition for isolate KF 2870

Mean inhibition for isolate KF 844

Fig. 2 A. A comparison of impact of 92 candidate antagonistic fungi isolates against two F. graminearum isolates KF 844 and KF 2870 in bioassay on PDA medium after 7 days at $25^{\circ} \mathrm{C}$ (in -8 to +8 scale of inhibition).

Fig. 2 B continued. A comparison of impact of 92 candidate antagonistic fungi isolates against two $F$. graminearum isolates KF 844 and KF 2870 in bioassay on PDA medium after 7 days at $25^{\circ} \mathrm{C}$ (in -8 to +8 scale of inhibition).

ranged from 9 to $20 \mathrm{~mm}$ /day (Tab. 1). Three chemotypes were identified using specific primers for PCR amplification of DNA among $F$. culmorum and $F$. graminearum isolates used in our experiments: 3 -AcDON chemotypes (mostly F. culmorum 
isolates), $15 \mathrm{AcDON}$ chemotype (most of $F$. graminearum isolates) and NIV chemotype (several isolates of both species).

Competitive abilities of candidate fungi against toxigenic Fusarium isolates were examined in dual culture bioassays on agar and solid substrate bioassay. Fusarium avenaceum, $F$. culmorum and $F$. graminearum produce aurofusarin and other carmine-red pigments on PDA medium (Vesonder, Goliński 1989). Trichoderma isolates produce a green pigment of polyphenolic nature. Colony pigmentation is a useful marker when studying the interaction between Fusarium isolates and their antagonists. Fusarium isolates growth in dual cultures with competitive isolates were visually reduced after 4 days. A week after inoculation growth inhibition and mycoparasitism of Trichoderma isolates were observed - the plate was green and overgrown with Trichoderma with significant production of abundant conidia in pustules over mycelium of Fusarium isolates, with only a small spot of the plate remaining red. Fusarium growth and red pigment production were strongly inhibited by isolates of T. atroviride, T. harzianum, T. hamatum, T. longibrachiatum and T. koningii.

Isolates of $F$. graminearum (KF 844 and KF 2870) were grown simultaneously with 92 antagonistic isolates and exhibited different susceptibility to the presence of the antagonists: isolate KF 2870 was significantly less resistant and isolate KF 844 exhibited a higher level of resistance against the same antagonistic mycoparasite (Fig. 2A, B). The antibiosis effect was not found in any of the candidate antagonists in dual culture on PDA.

The interaction between eight isolates of Trichoderma and six isolates of Fusarium is presented in tables 2 and 3 . Thus, on one hand the same Trichoderma isolate exhibited different antagonism against various Fusarium isolates, and on the other hand antagonistic isolates exhibited various aggressiveness against the same isolate of Fusarium.

Trichoderma isolates are able to produce antibiotics - inhibitors of other fungi (such as 6PAP), and several enzymes, which hydrolyse fungal structures - conidia and mycelia - and macromolecules - chitin, cellulose, hemicellulose, beta glucan, xylem and proteins (Lacicowa, Pięta 1985; Kubicek, Harman 1998; Cooney et al. 2001). This ability allows Trichoderma isolates to utilise the mycelium of Fusarium

Table 2

Growth inhibition of four isolates of $F$. graminearum and $F$. culmorum, belonging to three chemotypes (3AcDON, 15AcDON and NIV) by eight isolates of Trichoderma in dual cultures on PDA medium after 7 days at $25^{\circ} \mathrm{C}$ (in -8 to +8 scale)

\begin{tabular}{llcccc}
\hline \multirow{2}{*}{$\begin{array}{c}\text { Accession } \\
\text { code }\end{array}$} & $\begin{array}{c}\text { Antagonist } \\
\text { species }\end{array}$ & $\begin{array}{c}\text { KF 350 } \\
\text { F. culmorum } \\
\text { NIV }\end{array}$ & $\begin{array}{c}\text { KF } 846 \\
\text { F. culmorum } \\
\text { 3Ac-DON }\end{array}$ & $\begin{array}{c}\text { KF 844 } \\
\text { F. graminearum } \\
\text { 15Ac-DON }\end{array}$ & $\begin{array}{c}\text { KF 2870 } \\
\text { F. graminearum } \\
\text { 15Ac-DON }\end{array}$ \\
\hline AN 13 & T. harzianum & +4 & +6 & +8 & +8 \\
AN 16 & T. atroviride & +5 & +6 & +5 & +6 \\
AN 35 & T. atroviride & +7 & +8 & +8 & +8 \\
AN 89 & T. citrinoviride & +2 & +2 & +8 & +8 \\
AN 90 & T. atroviride & +4 & +6 & +8 & +8 \\
AN 92 & T. harzianum & -2 & 0 & -2 & +6 \\
AN 93 & T. viride & +8 & +4 & +6 & +6 \\
AN 94 & T. harzianum & +2 & +2 & +2 & +4 \\
\hline
\end{tabular}


Table 3

Growth inhibition of two isolates of Fusarium avenaceum in dual culture by eight isolates Trichoderma (in -8 to +8 scale) on PDA medium after 7 days at $25^{\circ} \mathrm{C}$

\begin{tabular}{|c|c|c|c|}
\hline \multirow{2}{*}{ Accession code } & \multirow{2}{*}{ Antagonist species } & \multicolumn{2}{|c|}{ Fusarium avenaceum isolate } \\
\hline & & KF 203 (ATCC 64451) & KF 2818 \\
\hline AN 13 & T. harzianum & +4 & +4 \\
\hline AN 16 & T. atroviride & +5 & +4 \\
\hline AN 35 & T. atroviride & +6 & +7 \\
\hline AN 89 & T. citrinoviride & +6 & +7 \\
\hline AN 90 & T. atroviride & +7 & +8 \\
\hline AN 92 & T. harzianum & +6 & +4 \\
\hline AN 93 & T. viride & +2 & +2 \\
\hline AN 94 & T. harzianum & +6 & +6 \\
\hline
\end{tabular}

as a source of nutrients. Our biotest experiments confirmed the mycoparasitism of Trichoderma species over all three species and chemotypes of toxigenic Fusarium.

Three types of interaction between Trichoderma species and plant pathogens have been recognized: antibiosis, competition for nutrients and hyperparasitism (Woo et al. 2006). No antibiosis was observed in our experiments. Results of our previous paper (Buśko et al.2008) correspond well with the finding of Cooney et al. (2001) on the impact of $T$. harzianum isolates on a DON-producing $F$. graminearum in the agar medium bioassay. The same authors proved the inhibition of DON production by a Trichoderma metabolite 6PAP, by as much as $80 \%$. The mechanism of DON content reduction in $F$. graminearum cultures remains unsolved. It was shown that DON when added to an agar medium inoculated with Trichoderma was not metabolised by the fungus (Cooney et al. 2001).

A question arises whether isolates of Trichoderma, growing on the mycelium of toxigenic Fusarium species, are also able to transform or degrade such mycotoxins as DON, NIV, MON, ZEA, and others - in total 19 mycotoxins identified in grain samples (Chełkowski 1998; Bottalico 2002). Until now, the ability to decompose DON has been found very rarely among microorganisms. Only one mixed culture among 1285 microbial cultures, isolated from farmland soil, cereal grains and others sources, transformed DON into two products that can be separated chromatographically (mainly 3-keto-4-deoxynivalenol; Voelkl et al. 2004).

In our previuos laboratory experiments $F$. culmorum and $F$. graminearum cultures grown on rice produced five trichothecenes: fusarenone $X$ (up to $21 \mathrm{mg} / \mathrm{kg}$ ), nivalenol (up to $3.7 \mathrm{mg} / \mathrm{kg}$ ), deoxynivalenol (up to $310 \mathrm{mg} / \mathrm{kg}$ ), 3Ac-DON (up to $228 \mathrm{mg}$ / $\mathrm{kg}$ ) and 15Ac-DON (up to $184 \mathrm{mg} / \mathrm{kg}$ ). Production of five trichothecene mycotoxins DON, 3AcDON, 15AcDON, nivalenol and fusarenone $\mathrm{X}$ was reduced by over $95 \%$ in dual culture bioassay by Trichoderma isolates AN 22 and AN 35 (Buśko et al. 2008). DON concentration in the bioassay in microcosms was reduced by $45 \%$ and fungal biomass was reduced by $15 \%$ in studies of Noef et al. 2006. Consequently, mean DON production per biomass was significantly lower - 36\% in dual culture with $T$. atroviride than in solitary culture of $F$. graminearum and the above mentioned authors did not find any evidence for the role of DON production in F. graminearum defence against $T$. atroviride. 
Table 4

Reduction of moniliformin produced by two isolates F. avenaceum in dual culture bioassay and decomposition of MON by Trichoderma harzianum AN 35 isolate on rice after 21 days at $25^{\circ} \mathrm{C}$

\begin{tabular}{cccc}
\hline $\begin{array}{c}\text { F. avenaceum } \\
\text { isolate }\end{array}$ & $\begin{array}{c}\text { MON produced by } \\
\text { F. avenaceum } \\
(\mu \mathrm{g} / \mathrm{g})\end{array}$ & $\begin{array}{c}\text { MON produced in dual culture } \\
\text { F. avenaceum/T. atroviride } \\
(\mu \mathrm{g} / \mathrm{g})\end{array}$ & $\begin{array}{c}\text { Reduction of MON } \\
\text { level }(\%)\end{array}$ \\
\hline $\begin{array}{c}\text { KF 203 } \\
(\text { ATCC 64451) }\end{array}$ & 58.5 & 3.4 & 94.2 \\
KF 2818 & 296.2 & ND & 100 \\
\hline $\begin{array}{c}\text { F. avenaceum } \\
\text { isolate }\end{array}$ & $\begin{array}{c}\text { MON } \\
(\mu \mathrm{g} / \mathrm{g})\end{array}$ & $\begin{array}{c}\text { MON after T. atroviride culturing } \\
(\mu \mathrm{g} / \mathrm{g})\end{array}$ & $\begin{array}{c}\text { Decomposition } \\
\text { efficiency }(\%)\end{array}$ \\
\hline $\begin{array}{c}\text { KF 2603 } \\
\text { (ITEM 3411) }\end{array}$ & 100 & 6.5 & 93.5 \\
\hline
\end{tabular}

A significant reduction of wheat head infection by $F$. graminearum and DON accumulation in kernels was found by Dawson et al. (2004) when ears were preinoculated by fungal antagonists, such as T. harzianum, Clonostachys rosea and $F$. equiseti.

Recently three major compounds exhibiting antifungal activity were identified to be produced by T22 and T39 isolates of T. harzianum, that are already used as active agents in a variety of commercial biopesticides (Vinale et al. 2006). Over 50 commercial biopesticides were found effective in biological control of soil and residue borne pathogens (Woo et al. 2005).

Fusarium avenaceum isolates produced moniliformin up to $100 \mathrm{mg} / \mathrm{kg}$ (Tab. 4). The isolate T. atroviride AN35 was found the most effective among the examined accessions against toxigenic Fusarium isolates used in this study. This antagonist was able to reduce moniliformin production in dual culture bioassay on rice by $95-100 \%$, depending on the applied $F$. avenaceum isolate. The same isolate reduced by $93 \%$ the amount of MON in a rice culture of $F$. avenaceum ITEM 3411 (KF 2603) - from $100 \mu \mathrm{g} / \mathrm{g}$ to $6.5 \mu \mathrm{g} / \mathrm{g}$ (Tab. 4).

The application of Trichoderma competitors may reduce growth of Fusarium species through competition in crop debris and mycotoxin production as well. However, the development of the formulation of biofungicides for practical control of diseases remains a very important task (Kubicek, Harman 1998; Woo et al. 2006).

Both in the literature and in our experiments presented in this paper significant interaction between toxigenic Fusarium species and Trichoderma competitotors was found to be of complex character, with importance of several characters such as growth rate, enzymes and secondary metabolites production (Harman 2006).

It can be concluded that competitive Trichoderma isolates are candidate fungi for biological control of toxigenic Fusarium species aggressive to cereals (such as F. culmorum, F. graminearum and $F$. avenaceum) and in reducing their inoculum, as well as preventing mycotoxin accumulation in plant tissues and crop residues in field.

It seems to be important to underline, that saprophytic species Trichoderma harzianum and T. atroviride are not antagonistic to A.bisporus. Both species isolates can be distinguished by DNA analyses from T. aggressivum, however when high amount of inoculum is present in mushroom compost both species may compete for nutrients with A.bisporus mycelium. Identification and nomenclature of Trichoderma species was recently modified by Gams and Bissett (1998). There is high similarity 
of Trichoderma isolates morphology under laboratory conditions and there are many confusions in the literature, concerning identification of species. Actual list of over 40 species and their descriptions are available on Website: http://nt.ars-grin.gov/ taxadescriptions/keys/TrichodermaIndex.cfm.

Acknowledgement. This study was partly supported by project no. PBZ-KBN-112/P06/2005 of the Polish Ministry of Science and Higher Education.

\section{REFERENCES}

Arseniuk E., Foremska E., Góral T., Chełkowski J. 1999. Fusarium head blight reactions and accumulation of deoxynivalenol (DON) and some of its derivatives in kernels of wheat, triticale and rye. J. Phytopathol. 147: 577-590.

Bai G., Shaner G. 1994. Scab of wheat: prospects for control. Plant. Dis. Reporter 78: 760-765.

Bottalico A., Perrone G. 2002. Toxigenic Fusarium species and mycotoxins associated with head blight in small-grain cereals in Europe. J. Pl. Pathol. 108: 998-1003.

Bottalico A. 1998. Fusarium diseases of cereals, species complex and related mycotoxin profiles in Europe. J. Pl. Pathol. 80: 85-103.

Buśko M., Chełkowski J., Popiel D., Perkowski J. 2008. Solid substrate bioassay to evaluate impact of Trichoderma on trichothecene mycotoxin production by Fusarium species. J. Sci. Food Agric. 88: 533-541.

Chełkowski J. 1998. Distribution of Fusarium species and their mycotoxins in cereal grains. (In:) K. K Sinha, D. Bhatnagar (eds). Mycotoxins in Agriculture and Food Safety. Marcel Dekker Inc., New York: 45-64.

Chełkowski J., Stępień Ł., Tomczak M., Wiśniewska H. 2002. Identification of toxigenic Fusarium species in wheat ears using PCR assay and their mycotoxins in kernels. Phytopathol. Pol. 25: 47-57.

Cooney J. M., Laurent D. R, Di Menna M. E. 2001. Impact of competitive fungi on Trichothecene production by Fusarium graminearum. J. Agr. Food Chem. 49: 522-526.

Dawson W. A. J., Jestoi M., Rizzo A., Nicholson P., Bateman G. L. 2004. Field evaluation of fungal competitors of Fusarium culmorum and F. graminearum, casual agents of ear blight of winter wheat, for the control of mycotoxin protection in grain. Biocontrol Sci. Techn. 14: 783-799.

Doohan F. M., Parry D. W., Jenkinson P., Nicholson P. 1998. The use of species-specific PCR - based assays to analyse Fusarium ear blight of wheat. Pl. Pathol. 47: 197-205.

Gams W., Bissett J. 1998. Morphology and identification of Trichoderma. (In:) Ch. Kubicek, G. Harman (eds). Gliocladium and Trichoderma. 1. Taylor and Francis, London: 3-34.

Harman G. E. 2006. Overview of mechanisms and uses of Trichoderma spp. Phytopathology 96: 190193.

Jones R. K., Mirocha C. J. 1999. Quality parameters in small grains from Minnesota affected by Fusarium head blight. Pl. Dis. 83: 506-511.

Kubicek Ch., Harman G. 1998. Gliocladium and Trichoderma. 1. Basic biology, taxonomy and genetics. Taylor and Francis, London.

Kwaśna H., Chełkowski J., Zajkowski P. 1991. Flora Polska. Grzyby (Mycota) 22: Sierpik (Fusarium). PWN, Warszawa-Kraków.

Leslie J. F., Summerell B. A. 2006. The Fusarium laboratory manual. Blackwell Publishing, Iowa, USA, $388 \mathrm{pp}$.

Liggitt J., Jenkinson P., Parry D. W. 1997. The role of saprophytic microflora in the development of Fusarium ear blight of winter wheat caused by Fusarium culmorum. Crop. Prot. 16: 679-685.

Luongo L., Galli M., Corazza L., Meekes E., De Haas L., Van Der Plas C. L., Köhl J. 2005. Potential of fungal antagonists for biocontrol of Fusarium sp. in wheat and maize through competition in crop debris. Biocontrol Sci. Tech. 15: 229-242.

Lutz M. P., Feichtinger G., Défago G., Duffy B. 2003. Mycotoxigenic Fusarium and Deoxynivalenol Production Repress Chitinase Gene Expression in the Biocontrol Agent Trichoderma atroviride. P1. Appl. Environm. Microbiol. 6: 3077-3084.

Łacicowa B., Pięta D. 1985. Injuriousness of some mycoparasites for pathological of Fusarium sp. Roczniki Nauk Rolniczych PWN, Seria E, 15 (1/2): 87-97. 
MacMullen M., Jones R., Gallenberg D. 1997. Scab of wheat and barley: a Re-emerging disease of devastating impact. Pl. Dis. 81:340-1348.

Mańka K. 1974. Fungal communities as criterion for estimating the effect of the environment of plant diseases in Poland. Zesz. Probl. Post. Nauk Roln. PAN 160, 9-23.

Noef A., Senatore M., Défago G. 2006. A microsatellite based method for quantification of fungi in decomposing plant material elucidates the role of Fusarium graminearum DON production in the saprophytic competition with Trichoderma atroviride in maize tissue microcosms. FEMS Microbiol. Ecol. 55: 211-220.

Nelson P. E., Toussoun T. A., Marasas W. F. O. 1983. Fusarium species. An illustrated manual for identification. The Pennsylvania Sate University Press, University Park and London.

Nicholson P., Simpson D. R, Weston G., Rezanoor H. N, Lees A. K, Parry D. W, Joyce D. 1998. Detection and quantification of Fusarium culmorum and Fusarium graminearum in cereals using PCR assays. Physiol. Mol. Pl. Pathol. 53: 17-37.

Nirenberg H. A. 1981. A simplified method for identifying Fusarium sp. occurring on wheat. Can. J. Bot. 59: 1599-1609.

Parry D. W., Jenkinson P., McLeod L. 1995. Fusarium ear blight (scab) in small grain cereals - a review. Pl. Pathol. 44: 207-238.

Quarta A., Mita G., Haidukowski M., Santino A., Mule G., Visconti A. 2005. Assessment of trichothecene chemotypes of Fusarium culmorum occurring in Europe. Food Additives and Contaminants 22: 799-815.

Savoie J. M., Mata G. 2003 Trichoderma harzianum metabolites pre-adapt mashrooms to Trichoderma aggresivum antagonism. Mycologia 95: 191-199.

Schilling A. G., Möller E. M., Geiger H. H. 1996. Polymerase chain reaction-based assays for species specific detection of Fusarium culmorum, F. graminearum and F. avenaceum. Mol. Plant Path. 86: $515-522$.

Sutton J. C. 1982. Epidemiology of wheat head blight and maize ear blight caused by Fusarium graminearum. Can. J. Plant Path. 4: 195-209.

Task Force Report. 2003. Mycotoxins: risks in plant, animal, and human systems. Council for Agricultural Science and Technology, Ames, Iowa, USA.

Tomczak M., Wiśniewska H., Stępień Ł., Kostecki M., Chełkowski J., Goliński P. 2002. Deoxynivalenol, nivalenol and moniliformin occurrence in wheat samples with scab symptoms in Poland (1998-2000). Eur. J. Plant Path. 108: 625-630.

Trichoderma and Hypocrea Taxonomy site. http://nt.ars-grin.gov/taxadescriptions/keys/TrichodermaIndex. $\mathrm{cfm}$

Vesonder R. F., Golinski P. 1989. Metabolite of Fusarium. (In:) J. Chełkowski (ed.). Fusarium, mycotoxins, taxonomy and pathogenicity. Elsevier Scientific Publishers, Amsterdam: 39 pp.

Vinale F., Marra R., Scala F., Ghisalberti El., Lorito M., Sivasithamparam K. 2006. Major secondary metabolites produced by two commercial Trichoderma strains active against different phytopathogens. Lett. App. Microbiol. 43: 143-148.

Voelkl A., Vogler B., Schollenberger M., Karlovsky P. 2004. Microbial detoxification of mycotoxin deoxynivalenol. J. Basic Microbiol. 44: 147-156.

Wakuliński W., Chełkowski J. 1993. Fusarium species causing scab of wheat, rye and triticale in Poland. Hod. Rośl. Aklim. Nasien. 37:137-142.

Woo S. L., Scala F., Ruocco M., Lorito M. 2006 The molecular biology of interactions between Trichoderma sp., phytopathogenic fungi and plants. Phytopathology 96: 181-185. 
Antagonistyczne oddziaływanie wybranych grzybów na toksynotwórcze gatunki Fusarium patogeniczne dla zbóż

\section{Streszczenie}

Fuzarioza kłosa jest w wielu regionach produkujących zboża chorobą wyniszczającą i powoduje straty powstające na skutek obniżenia plonowania i jakości ziarna. Ziarno z roślin porażonych jest zanieczyszczone mikotoksynami, przede wszystkim deoksyniwalenolem i jego pochodnymi, zearalenonem i moniliforminą. Gatunki Fusarium dobrze rozwijają się na resztkach pożniwnych i obficie na nich zarodnikują. Grzyby saprotroficzne o cechach antagonistycznych wobec tych patogenów mogą przyczyniać się do zmniejszenia zarodnikowania patogenów Fusarium i obniżenia ilości tworzonych przez nie mikotoksyn.

Antagonistyczne oddziaływanie 92 izolatów grzybów należących do 29 gatunków testowano w bikulturach z izolatami trzech toksynotwórczych gatunków $F$. avenaceum (Corda) Saccardo, F. culmorum (W.G.Smith) Saccardo i F. graminearum Schwabe. Gatunki F. culmorum i F. graminearum tworzą mikotoksyny trichotecenowe i mikohormon zearalenon oraz należą do najistotniejszych patogenów zbóż w skali światowej. Porażenie kłosów zbóż przez te gatunki powoduje akumulację w ziarniakach deoksyniwalenolu (DON) i zearalenonu (ZEA). Izolaty F. avenaceum tworzą moniliforminę (MON) i enniatyny.

Izolaty gatunków Trichoderma okazały się najbardziej efektywnymi dla redukcji wzrostu izolatów wymienionych gatunków. Efekt antagonistyczny poszczególnych izolatów Trichoder$m a$ względem tych samych izolatów Fusarium różnił się znacząco. Również stopień redukcji wzrostu poszczególnych izolatów Fusarium przez te same izolaty Trichoderma był znacząco różny. Ilość moniliforminy produkowanej przez dwa izolaty $F$. avenaceum w bikulturach na ryżu była redukowana o 95-100\% przez izolat T. atroviride AN35. Ten sam grzyb antagonistyczny redukował zawartość moniliforminy z poziomu $100 \mu \mathrm{g} / \mathrm{g}$ do $6.5 \mu \mathrm{g} / \mathrm{g}$ w kulturze na ryżu, co sugeruje możliwość dekompozycji tej mikotoksyny przez ten izolat. 